\title{
Transatlantica
}

Revue d'études américaines. American Studies Journal

\section{Ambivalence and Ambiguity in The Autobiography of Miss Jane Pittman}

\section{Monica Michlin}

\section{Q OpenEdition}

1 Journals

\section{Édition électronique}

URL : http://journals.openedition.org/transatlantica/1092

DOI : $10.4000 /$ transatlantica. 1092

ISSN : 1765-2766

Éditeur

AFEA

\section{Référence électronique}

Monica Michlin, «Ambivalence and Ambiguity in The Autobiography of Miss Jane Pittman »,

Transatlantica [En ligne], 1 | 2006, mis en ligne le 03 mai 2006, consulté le 29 avril 2021. URL : http:// journals.openedition.org/transatlantica/1092 ; DOI : https://doi.org/10.4000/transatlantica.1092

Ce document a été généré automatiquement le 29 avril 2021

\section{(c) (i) (9)}

Transatlantica - Revue d'études américaines est mis à disposition selon les termes de la licence Creative Commons Attribution - Pas d'Utilisation Commerciale - Pas de Modification 4.0 International. 


\title{
Ambivalence and Ambiguity in The Autobiography of Miss Jane Pittman
}

\author{
Monica Michlin
}

1 Although AMJP, as a "folk autobiography" spanning a hundred years of white oppression, is undoubtedly meant as oral testimony to the people's having endured, it is sometimes made ambiguous by the ambivalence that characterizes Miss Jane, and Gaines's staging of her. As a child, Jane's ambivalence, and distrust of adults translates into "smartness," which marks her out as a rebel and makes hers a resilient voice. As her narrative unfolds, however, her signifying on heroic black speech, and her increasing interaction with paternalistic Whites seem to cast her as swinging between such stereotyped roles as the mammy, the trickster, or the benevolent ancestor for symbolic sons within the story (Ned and Jimmy), who slowly convert her to black political action. Yet this didactic narrative seems ambiguous on two levels: first because the suspended ending illustrates the difficulty of resolving the political contradictions staged; and second because while this folk history is told by Miss Jane, it paradoxically does not-to subvert what the interviewer initially claims as his goal-have "Miss Jane in it" (v). I mean by that that Gaines's very aesthetics undermine his project, since the flatness of Miss Jane's voice, the suppression of all intense feelings (from shame to pain) as well as the absence of her body as locus of her oppression as a black woman, keep her one-dimensional and prevent reader participation of the kind women's neoslave narratives ${ }^{1}$ provoke. Does this point to Gaines's own ambivalence towards a narrator who is undoubtedly the "protagonist" of the narrative, but is neither its heroine (male heroes take center-stage), nor even its most vibrant voice? Or does it point to mine, as a womanist reader? I will analyze ambivalence as a fundamental characteristic of black relationships but also black-and-white relations throughout the novel; point to the ideological ambiguities and contradictions in Gaines's choice of voice; and finally examine whether this "speakerly text," in failing to make Jane a compelling presence and embodied self, does not fail at provoking the reader participation the introduction calls for. 
2 The entire narrative is placed under the sign of ambivalence: Mary, who acts as Miss Jane's "voice-guard," signifies, against the interviewer's desire to hear her story: "You don't have to say a thing" (v) and "I can always borrow Etienne's shotgun" (vi). While staged as a piece of comedy, this threat highlights the "armed resistance" that protects the vernacular voice against editing and/or coercion. Telling the story is a form of empowerment, and the rambling the interviewer-editor complains about is Miss Jane's refusal of an imposed order: Mary again bluntly spells this out: "And if you got to change her way of telling it, you tell it yourself. Or maybe you done heard enough already?" (vii). This signifying within the frame is a key to the entire narrative: it creates a humorous aural contract that aligns our sympathies with Miss Jane, while drawing our attention to ambivalence in speech and dialogue. It also raises our awareness as to Miss Jane's being the sole teller of her story, although Gaines had initially thought of making the novel polyphonic, as he explains in his interviews; which implies that Miss Jane's perspective filters the entire narrative.

The first-person speakerly text initially creates a feeling of immediacy, especially since Jane's uneducated voice echoes the voice of the child that she was then ("little old black me," 4). ${ }^{2}$ Slavery in the first chapter is represented physically, through the repetition of backbreaking work ("buckets after buckets after buckets," 4), but especially, through the mistress's absolute denial of Jane's status either as a human being or as a child. The chapter begins with her threatening that the Yankees are going to eat Jane ("you don't want them boiling you in oil and eating you, do you?," 6) and ends on her whipping Jane until she bleeds for refusing to going back to being Ticey, thus fulfilling her seemingly empty threat of the opening scene ("I'll have you skinned," 6). There thus seems to be no ambiguity in the first scene, which pits the liberating Yankee soldier, Corporal Brown, whose performative, paternal speech-as opposed to what we will see at length, Southern paternalism-consists in addressing Jane as a child, renaming her for his little girl, and promising to fight for her, against the white mistress and the "Secesh." His speech to Jane can also be read as a unambivalent reformulation of the young Secesh's extremely ambivalent complaint ("griping"): "Just left to me, I'll turn them niggers loose" $(6,7)$. Because the South is so inextricably linked to slavery and to a history of black pain, as the chorus of recently emancipated black voices testifies to ("I done seen babies jecked from mama's titty," 15), Jane is bent on going to Ohio, thinking, in an illustration of the black hunter's later quip-"like freedom was a place" (46) - that as Corporal Brown's state, it is the best place to set down the roots she has lost ("I didn't have a mama or a daddy to cry and hold me back, 14).

From the start, however, her relations with Blacks and Whites alike are fraught with ambivalence when they are not merely defined by violence. ${ }^{3}$ Jane's refusal that the "loon" take the name "Brown" climaxes with her taking a stick to "crack his head open" (19). While she finds herself losing the fight and saved in the nick of time from rape by Big Laura, the massacre scene echoes this passage on two levels. First, the "slow-wit" is killed by the patrollers exactly in this way ("I could hear his head crack like you hear dry wood break," 22), but the change of noun shows that Jane regrets that he meets this fate (she no longer expresses contempt); second, she has to overcome contradictory feelings to save Ned: "I wanted to jump up from there and run-but what about Ned? I couldn't leave him there-look what Big Laura had done for me just yesterday" (22). After the massacre scene, her determination to go to ohio is heightened by the flight from traumatic memory, since Big Laura's death calls up 
memories of her own mother's death by beating $(29,33)$ : "I looked at it this way, we had to keep going. We couldn't let what happened yesterday stop us today" (25); or "I was doing everything to keep from thinking about anything but going to Ohio" (32). Jane's "pig-headedness" (47) as to Ohio is thus a matter of resilience; but it leads to conflictual feelings and often, to conflict, each time someone advises her to give up her quest. When she meets the white woman who pleads: "child, child, there ain't no Ohio [...] Y'all come back with me [...] I'll treat you right" (30), Jane views this plantation owner's tears with the double ambivalence of a numb survivor and an ex-slave: “I didn't cry, I couldn't cry. I had seen so much beating and suffering; I had heard about so much cruelty in those "leven or twelve years of my life I hardly knowed how to cry" (24). She later similarly "escapes" from the Freedom Beero orphanage, despite knowing she and Ned will probably not be "mistreated," ${ }_{4}^{4}$ and because the school bell reminds her of the plantation. Confusing two types of work, one that is necessarily alienation, and one that carries the promise of liberation ${ }^{5}$ - $A B C$ and numbers was something I wasn't ready to start on yet. And the Lord knows I had heard enough bells in them "leven or twelve years" (39)-she prefers, in classic fairy tale fashion, to once again take Ned through the dangerous woods that in fact do not lead to Ohio at all.

When Jane meets the black hunter, she cannot help swinging from happiness at finding a helper, in Propp's terminology, to resentment at his teasing her (albeit kindly). ${ }^{6}$ As a result, she "[gets] smart" (47) once again. As an adult narrator, Jane frames the exchange to show the reversal of power she felt as a child-from "I didn't want to argue with him no more" (46) to "He didn't want to argue with me no more" (48)-but illustrates that her victory was short-lived ("Well, how was Ohio?," 48), and implies that she only realizes the next day that she has again lost a benevolent father-figure.

The scene is repeated with a variation in color, when she meets the very helper who can provide all the Hunter has told her she lacks-"no map, no guide, no nothing" (46). But Jane's inability to read the Old Man's face-"his face was red red; not kind, but not mean either" (50); “his face wasn't kind, but it wasn't mean either" (53)-repeats and amplifies her inability to read the map. This in turn causes her to suspect that he is a villain in disguise. Much in his actions is ambivalent: he has offered food, but without a spoon (51), and looks with disgust at the crumb she has accidentally sprayed onto the map (52), but speaks to her as an equal (52): these mixed messages increase her insecurity. As he reads the map to her in meaningless-or magical-terms ("lat and longi"), she finally realizes that she has been foolishly obstinate until then-"All of a sudden it came to me how wrong I had been for not listening to people. Everybody, from Unc Isom to the hunter, had told me I was wrong. I wouldn't listen to none of them" (51)-but on the other hand, she reverts to suspicion as a defense against despair: "No, I wasn't go'n cry. I was go'n be strong. I looked at the old man standing at the map. How did I know he was telling me the truth? How did I know he wasn't just another older Secesh trying to get me woolgathered?" (51). She finally asks him outright "How I know you ain't a Secesh?" (53). His answer is a signifying; he offers that he might be "Secesh," but also "a friend of your race" (53)-that he might in fact be "anything" (54). Jane comments neither on this ambivalent reply, nor on his portrayal of himself as an old man who cries at night and who is on the brink of suicide (53), perhaps because this too closely reminds her of her own trauma. She simply reaffirms her own "contrariness" when the Old Man concludes his demonstration: “"The boy'll 
never make it,' he said. You? I figure it'll take you about thirty years. Give or take a couple.' 'Well, we'd better head out,' I said." (57).

Despite the humor in all of these scenes, Miss Jane's incapacity to distinguish friend from foe is also revealed; as well as her subconscious drive to make the wrong choice in the belief that she is defending herself against tricksters. This repeats itself when, as an adult, Jane goes to the "hoodoo." While she insists that she does not "believe in hoodoo" (96), and puts Madame Gautier's supposed rivalry with Marie Laveau down to self-promotion-"At least, that was her story" (96)-as the scene unfolds, and as the answer to her question is deferred, she tries to counter her growing fear with "sassiness." She tries to negotiate a "good" answer, then to talk around the "oui" that spells out Joe's death; and when the hoodoo outsignifies her, she questions the latter's authority to her face. The hoodoo's response is a theatrical self-authorization ("I am Madame Eloise Gautier, formerly of New Orleans," 99, 100), but she convinces Jane more through her blasé dismissing of objections ("I know, mon sha, I know," 100). Although Jane buys a magic powder to temporarily protect Joe, she goes from feeling "good," to feeling "shaky" the next; another formulation for the pendular movement which typifies her ambivalence. An entire paragraph in free indirect speech reflects her justification for renewed distrust, which leads in turn to her freeing the black horse, and hastening Joe's death.

Jane never expresses pain over the fact that her last contact with Joe is as he knocks her down (102) to ride to his death; nor does she express regret at not having trusted the hoodoo: "but even then I didn't believe [the hoodoo] the way you suppose to. I went to her because nobody else would listen to me. But after I had gone I still didn't take her advice" (128). Where is the guilt at having caused the death of the man who was "good" to her (97), who was a "real man" (81), and whom she loved so that she kept his name (103)? ${ }^{7}$ The absence of mourning either for Joe, or for the man who briefly replaces him (in one paragraph) and as quickly exits her life, makes Jane seem extremely defensive, and reticent to speak of emotion, or, more simply, unrealistic as a character; and the telescoping of Joe's death and Ned's return emphasizes that Jane only exists as a wife to Joe, a mother to Ned, or a servant on the Samson plantation. This raises the question of Gaines's own ambivalent staging of Jane: as the protagonist, but not the heroine, of a narrative staging black male heroism, and seemingly leaving her the role of ...mammy.

9 Indeed, as an adult, Jane-the-rebel has become prudent to the point of ambiguity. In a literal acting-out of the hunter's quip "You ain't even left that plantation yet" (46), she changes from the survivor who has done nothing but be "out there" (62), to one who only confronts white power head-on out of love for Ned, Joe, or (later) Jimmy. Ned comes close to calling his adoptive mother a mammy: although Jane bravely defends him against the Klan, he answers her quipping that she is, in a way, "married" (78) to the Dye plantation, with the harsh retort: "You'll be a dog [...] to eat the crumbs they throw on the floor" (78). Although Jane answers with dignity ("you know I'm not a dog"), ${ }^{8}$ she also admits she is not ready to act: "This is not my time" (78). The phrase necessarily brings to mind the famous anaphora at the heart of Martin Luther King Jr.'s "I Have A Dream" speech. ${ }^{9}$ How does Miss Jane present her own ambivalent relationship to white paternalism and to black heroics both?

10 Throughout her story, she stages the constant use of (in)direct insult on the part of "paternalistic" Whites: Colonel Dye (85), the sheriff (124), Robert Samson and the 
policeman (231) all use the word "nigger" deliberately, to harass and intimidate. Since Whites make the rules, words like "good" and "bad," are constantly perverted, as Jane demonstrates in her flashback on what happened to runaways during slavery: "If you was a good slave, a good worker, they would bring you back home and beat you." (73). The grim punchline of the last two words drives home the irony of being beaten for being "good." If she does not critique these terms explicitly, she stages them too ironically for us not to perceive that she does not internalize these white definitions; she later points out the same irony of the adjective "good" under segregation: "Freedom here is able to make a little living and have the white folks say you good." (250). Jane also reveals white paternalism as a thin mask for outright violence: Colonel Dye asks Joe for money for "protection" from the Klan; ${ }^{10}$ the sheriff harasses witnesses to Ned's shooting, covering death threats in a thin veneer of signifying; Robert Samson plays out an entire humorous monologue on his sharecroppers' exploiting him (232) the better to threaten them with eviction if they join in any civil rights demonstrations.

11 Jane's voice is absolutely clear on these issues; from staging her ex-master's hypocritical "y'all free [...] If y'all stay I promise I'll be fair as I always been with y'all" (11), to her describing how during Reconstruction, plantation owners used the "secret groups" (70) like dogs "loosed on the people" (74) and voicing her suspicion that Colonel Dye has sicked the Klan onto Ned (77). Not only does she not believe in white landowners being friends, but she has no desire to approach the white landowners at all. She stresses her political consciousness as a field worker-"House niggers always thought they was better than field niggers" (88)-and explains that she tries to refuse any greater proximity with Whites as house cook: "I told them to let me go work in the field. No, they said" (91). The chapter called "Molly" is a little fable on the fatal internalization of white paternalism: Molly, the woman that Jane was unable to mollify is the archetype of the conflicted mammy, ${ }^{11}$ who absurdly dies for love of the white "Miss" (91). Later in the narrative, on the Samson plantation, when Tee Bob's affection for her-and not the converse-prompts Paul Samson to make her house cook, she once again tries to refuse: "I didn't want to go up there, I loved the outside so much" (147). When she dares to quip to Samson that she has never poisoned any Whites yet, in an open display of ambivalence, the white man, while recognizing her verbal prowess ("show me if you can make biscuits smart as you can talk," 147), shows the limits of black wit as a form of resistance. He concludes the exchange with a signifying on the alternative Jane faces-either to obey or to leave immediately.

Thus forced into closer relationship with Whites, Jane does not forget that she is a black woman in a white man's world: not only does she not "mammy" the Samsons, but she warns Mary Agnes that Tee Bob will not "stay decent" (178), considering him not to be good, but to be weak. ${ }^{12}$ The chapters concerning her attempt to protect Mary Agnes illustrate that Miss Jane is not a mammy but a trickster, who tries, through mere bodily presence, and indirect verbal allusions, to thwart Tee Bob's attempts to see the young woman. Her consciousness that she is powerless, however-"who was Jane Pittman to tell Robert Samson Junior what he ought to do or what he ought to not do when anytime he wanted to he could tell me to shut up my black mouth?" (173)-forces her, as trickster, to play the mammy: "You want me to [...] tell your mama you sassed me, Tee Bob?;" "you getting smart with me, Tee Bob?," 180). But this too proves ineffective: Miss Amma Dean prefers to deny the truth her servant tells her (181), rather than have to symbolically admit that the color and class lines that separate her from Jane, and Tee Bob from Mary Agnes, are arbitrary. When the double tragedy of the (near?)-rape and 
suicide occurs, Miss Jane does her utmost, alongside Jules Raynard (whose name evokes Brer Fox), to protect Mary Agnes; but she cannot escape the double-bind of white paternalism and black mammy-ism when she hears out Raynard's sexually and racially biased version of her own, and Mary Agnes's guilt in Tee Bob's death. Although Gaines points to the narrative frame-Miss Jane is in the back seat of Raynard's car-to pun on it (she takes a backseat to what he, the white man, has to say), this collaboration in "specalatin" (205) is ambiguous, especially since Miss Jane does not criticize Raynard's speech after the fact. We are instead led to believe that she was ambivalent towards Mary Agnes for both class and racial reasons all along, in an echo of all the tensions between Blacks staged within the novel. ${ }^{13}$

In this sense, Jane seems so ambivalent that she has no loyalty except to Ned, Joe, Ned again, and Jimmy, successively. Perhaps this callousness explains why in a tragic irony, she had bonded with the Cajun killer who eventually assassinates Ned. While she professes horror at Cluveau's stories of murder (107), she nevertheless admits: "no matter how he talked I would sit there and listen to him" (107). The ambiguity of thisdoes she listen because she likes a good story, does not want to offend him, or thinks this relationship protects her?-is brought to a head when Cluveau starts to hint that there is a contract on Ned. While Jane seems to hope that the fishing, coffee and talk they have shared mean he will refuse to kill her "son," Cluveau, when asked outright, admits to the contrary. The reality of racial warfare is brought home too late; and Jane's naïve belief-perhaps reflected by the onomastics of her horse, Pigeon, if Gaines knows the figurative meaning of this in French-that she could manipulate or pacify Cluveau shows the limits of tricksterism.

This is constantly stressed: Colonel Dye tells Jane "don't just talk" (77), Robert Samson resists Yoko's quoting his own words (that she has been one of the best workers on his plantation) or her plea that she has lived there for fifty years: he gives her "twentythree hours and fifty-nine minutes" to pack her things and leave (233), in a signifying on her having wasted one minute of talk. While Jane clearly ascribes Yoko's death, one year later, to this eviction, she nevertheless repeats Samson's joke on burying Yoko on his plantation as long as she doesn't demonstrate in the graveyard (235) without commenting on the cruelty of this. What are we to make of the dark humor in her staging sadistic white witticisms, whether Samson's or the sheriff's $(123-125,165)$ ? If we are meant to recoil at white violence, why is there so little overt pain or anger?

This question is at the heart of Jane's ambiguities. Gaines seems to have wanted to use her as an allegorical representation of ordinary black people in their ambivalence towards black heroics. In the didactic unfolding of Miss Jane's life, he means her first to testify and pass on the heritage of black heroics embodied by Ned; then to nurture Jimmy, the messianic non-violent figure who functions as an obvious stand-in for Martin Luther King Jr. But how can the author achieve what amounts to an about-face? Indeed, in "Exodus," when Jane describes the man who chose to be shot by the patrollers rather than being taken back to slavery, she excludes both lyricism and pathos, and debunks the man's heroic gesture through cruel bathos: "He told them he rather they shoot him down like a dog than go back and he tored his shirt open to let them shoot at his heart. They shot him right where he was and left him back there for the buzzards" (73). The word "dog" is absolutely shocking-can the man really have used this self-debasing image? Is Jane parroting the patrollers' speech? She similarly uses the harsh terms "the dumb ones" (74) for the runaways who attempt to wade 
through the bayou and drown. Gaines's "reworking" of the heroic in Jane's consciousness is that these unfeeling terms ${ }^{14}$ are recast without ambivalence in Ned's Sermon at the River and in the scene of his death, when he too refuses to die like a dog (refusing to "crawl"), and similarly dies shot in the chest. Even if Jane thinks that "his talk by the river that day definitely hurried him to the grave" (112), she replaces a sarcastic quip like "that bayou got more people in it than a graveyard" (74), with a lyrical celebration of the "precious blood" Ned has shed for future generations, explicitly contrasting it with the "precious blood of the South" ("the Secesh soldiers") her ex-mistress cried over during the Civil War (119).

Although Jane doubly celebrates Ned's memory, by keeping the school and the memory of Ned alive, and by transmitting that memory to us, she also echoes ordinary black people's fear of the hero who wears his Army uniform (104) to declare war to white power: "But the people wasn't listening. Not that they didn't believe what he was talking about, but they had already seen too much killing. And they knowed what he was preaching was go'n get him killed, and them too if they followed" (106). Although Jane resents the people's belated homage-“They didn't want to go near him when he was living, but when they heard he was dead they cried like children" (122) -, her own perspective is split: she remains a "gradualist" herself, while acting as the narrative mediator of Ned's revolutionary speech ("wouldn't you rather die saying I'm a man than to die saying I'm a contented slave?," 117). Gaines attempts to work through this contradiction by staging her ambivalent conversion to the Civil Rights Movement: although she speaks of "all of that Civil Rights trouble" (230), she also voices her admiration for the children of Little Rock: "I'll take the memory of it to my grave just like I will take this scar on my back to my grave" (231).

Miss Jane's reference to this scar-the first since the whipping took place in the opening chapter-announces her return as rebel, resuming her "travels" at the close of her life. ${ }^{15}$ She recognizes the ambiguity that old age now makes her impervious to the threat of white violence. As a child, she knew she represented harmlessness to Whites -"I stood up so he could see I was a little girl" (33); "I was nothing but a child, and a little black one at that" (63) - now, she knows age paradoxically emboldens her: "But look at me acting high and mighty. Don't the black curtain hang over my window; don't the veil cover my face? And maybe, now, because my arms too weak to push the quilt down the bed I tell myself I'm brave enough to go to Bayonne" (250).

Miss Jane still believes, however, that Jimmy is idealizing "the people." We belatedly realize that this is an example of the defeatism that Ned decried in his Sermon (115): her fundamental disbelief in change prevents her from being a "black American"-but the dynamics of the novel allow the change in her. While she projects her own fear in asserting "the mark of fear, Jimmy, is not easily removed" (242), and in countering the revolutionary "retrick" (243) of call and response with proverbial certainties in black and white-"Nothing out there now but white hate and nigger fear" (241)-or with dramatized incredulous questions (248-49), ${ }^{16}$ she sees, when the people of the Quarters gather, that she was wrong not to believe. As she herself converts to the struggle, she thinks of what she will say to Jimmy and what he will answer: "And he was go'n look at me in that sad-sweet way and say, "Sure, I knowed they wasn't go'n let me down" (258). The image immediately calls up that of Jimmy's looking down from the cross which Miss Jane has said all men who fight for the poor end on (160). So when Robert breaks the news that Jimmy has been shot, religious and political imagery come 
together, in Miss Jane's beautiful reply-“Just a little piece of him is dead [...] The rest of him is waiting for us in Bayonne" (259)-in which the image of Jimmy as Christ combines with the hymn "John Brown's Body."

The political charge lies in Miss Jane Brown's marching on, past Robert. The exchange of gazes-"Me and Robert looked at each other there a long time, then I went past him" (259)-encompasses all of the ambiguities and the ambivalence of black and white relations in the novel. The words "me and Robert" bring to the forefront the ambiguities of the "and" which has bound Jane to Robert all along: she is more like Robert than any other character in the novel, in her own refusal of emotion, her love of signifying, her apparent disillusionment. By quitting her job as house cook and returning to the Quarters-the title of the last book of the novel-despite Robert's signifying on her decision (213), she has taken a first step. Now, as she goes "past" him, she marks her final rejection of white paternalism.

The narrative incongruity of this literal exit from her own narrative raises a number of questions. The frame Gaines initially set up literally explodes: the ellipsis between the end of the novel and the present yawns wide. There is no explanation for Miss Jane's still living in the Quarters, eating vanilla ice-cream (in a symbolic reversal of her exmistress's threat of white people eating her boiled in oil) and enduring ${ }^{17}$ (219) after the march on Bayonne. Of course, Gaines's didactic novel allows him to reconcile all the ambiguities that are unresolved within the narrative. Miss Jane's "flint and iron" narrative finally produces that "fiyer" (34) that reunites her with Ned and Jimmy-but this only draws our attention to her having become an allegorical figure of the people (beyond being the oral mediator of the people's folk history) in the book's final political message.

Miss Jane's absence from her own story is due to the suppression of the language of the body which ultimately derealizes her. When Angelyn Mitchell defines the typical "antebellum slave narrative" as revolving around the "heroic male" (8) and the contemporary womanist neo-slave narrative as not being merely "emancipatory" but "liberatory" (xii) in its very poetics, she pinpoints the difference as lying in the "quintessential Black feminist theme:" "the self" (5). This Miss Jane is not: she exists primarily as an ancillary character to heroic males, from the second part of the novel onwards. While the lack of intimacy with, or interiority of, Miss Jane need not be ascribed to the author's ambivalence towards his female protagonist ${ }^{18}$-and although it may be inherent to the almost "documentary" aspect of his novel, which also characterizes Margaret Walker's Jubilee, ${ }^{19}$ beyond the question of genre posed by the "linear historical narrative," there remain obvious issues of the gendered body.

From the end of the first chapter, when Jane is whipped, intense bodily sensations and emotions, which are crucial to creating empathy and to implying readers are (nearly) suppressed, ${ }^{20}$ contrary to what happens in Jubilee, and even more so in Sherley Anne Williams's Dessa Rose, or Toni Morrison's Beloved, where graphic imagery and/or firstperson expression of agony force us to internalize what we read. When Jane later refers to the scar on her back, very late in the novel (242), it remains a mere word: we have never seen it nor felt that it (re)defined her in any way. Jane's strangely remote voice mainly stages white speech, even when extreme physical violence is unleashed in the massacre scene. We hear the screams and the patrollers' vindictive racism ('They ain't human. Gorilla, I say," 23) -but see almost nothing. White violence is filtered verballythe hunter mentions a lynched black man $^{21}$ but in passing-perhaps out of pride and a 
refusal to appear "victimized" rather than oppressed; perhaps because Gaines thought that reader participation would come from a need to compensate the narrative voice's dryness. The difficulty for me today is that I remember having been shocked and moved by this novel the first time I read it, when I was twenty or so; but since, the emancipatory narratives I have read have made me ambivalent to both this muting of violence, and the "silencing" of Jane as a woman.

Although, as Cheryl Wall points out in Worrying The Line (2005), black women's novels were initially put down precisely within a gendered debate on aesthetics and ideology (220) for their focus on "intimate relationships" (6) whether black and white or black and black, this is precisely what seems missing in AMJP from a feminist perspective today. By erasing Miss Jane's body between the moment where the "loon" almost rapes her, and the moment when she speaks of her very aged body's weakness, Gaines precisely sidesteps the main locus of feeling and memory. While this is in part due to the narrative frame-a very old lady speaking to a young man-that prohibits any form of intimacy, Gaines's ability to intimately represent the terror and violence exerted by Whites in other works shows this to be a specifically gendered issue. A major point that makes AMJP one-dimensional is that racial shaming is evoked, but mainly in Ned and Jimmy's speeches; while it is enacted in Brady's broken speech on his shame at being "scared" and at not being "a man" (252), ${ }^{22}$ it is not central to the novel, thus underrepresenting the reality of the trauma caused by racial oppression. On rereading J. Brooks Bouson, ${ }^{23}$ it strikes me just how this dimension is lacking in AMJP:

While in Toni Morrison's novels we find evidence of the desire to bear witness to the shame and trauma that exist in the lives of African Americans, in Morrison's insistent aestheticizing of shame and violence, we also find evidence of the reactive desire to cover up or repair the racial wounds she has exposed. (5)

What Bouson calls the "reparative urge" expresses itself, for instance, through the benevolent ancestor figure; or through the use of magic; or again, through celebration of the stigmatized black body. This dimension of "textual healing" which Mitchell also describes $(146)^{24}$ in connection to the wounded black body sometimes appears in Gaines's text, for instance, when Ned celebrates the bones of black people fertilizing the soil of the South (113), or when Jane resurrects Jimmy in the final lines ("only a little piece of him is dead"). But when she depicts the interiorized racial inferiorization of the people, with the image of the "black curtain," beyond Gaines's signifying on W.E.B. DuBois's The Souls of Black Folk, the image almost appears as an example of internalized racism, since even as Miss Jane speaks the necessity of breaking through white racist discourse, she cannot help staging black as negative. This echoes other instances of ambivalence towards blackness: although she describes Ned as being "real black" and "real handsome" (76), she also repeatedly connects blackness and evil, in the description of the horse that kills Joe-" Tall, slick, and black, just running long the fence. He was the devil, as far as I was concerned" (95) (repeated for effect at the end of the chapter)-but also, in her "travels," where Jesus appears as a "White Man with long yellow hair" (143) while the devil takes on the appearance of a "jet black" man (143). The scene with Madame Gautier signals her resistance to Africanness ${ }^{25}$ in clothing (dress and head-cloth, 96), in imagery ("Man is foolish [...] Some go after lions," 97) but also culturally, in hoodoo, in contrast to the way Morrison's Song of Solomon and Beloved, Toni Cade Bambara's The Salt Eaters, or Gloria Naylor's Mama Day-all post-modern 
narratives-rework magic doubly, within the text (as traumatizing and curative both), and reflexively, since the readers are drawn into the text-as-conjure.

In conclusion, although it is difficult to reread AMJP today without comparing it to what black women have written since-emancipatory narratives in écriture feminine -, it is, like Margaret Walker's Jubilee, a more traditionally political novel, a counter-plantation novel that passes on the legacy of the black people's enduring, in black vernacular. Miss Jane's voice is not primarily a character's voice; it is, allegorically, the voice of the people, in all of its ambiguities and contradictions. One can argue that Gaines chose an ending that magically resolves the ambivalence and ambiguities of the book in ways that metatextual comments throughout do not. But it is also important to place it in context. In 1967, Styron's ideological framing of the black male hero in The Confessions of Nat Turner showed black writers that there was still an urgency to writing counterplantation novels and reimposing the black perspective as opposed to a white one in blackface. ${ }^{26}$ Whatever the ambiguities in AMJP, and despite its casting Miss Jane, after her rebelliousness as a child, as a traditional figure both in terms of beliefs and of gender roles, the novel fundamentally seeks to reassert the vitality of black life, black speech, black culture despite the century of oppression it depicts. Gaines's ambivalence towards his protagonist can be put down to the same ambivalence Miss Jane shows towards "the people:" for she is the people, slowly preparing for her time. As Miss Jane walks out of her narrative, Gaines forces us to leave the space of the book too. While feminist readers and/or readers of more recent black post-modern fiction may feel ambivalence towards a traditional linear narrative that does not really make its narrator its heroine, the final political message seems clear enough, and precludes that this "folk autobiography" turn into another "dusty" History book: for with this ending, Miss Jane-the preface notwithstanding-never dies, and the struggle goes on, within, and beyond, the text.

\section{BIBLIOGRAPHIE}

ANDREWS, William L, “'We Ain't Going Back There:' The Idea of Progress in The Autobiography of Miss Jane Pittman." Black American Literature Forum. December 1977; 11(4): 146-149.

BAMBARA, Toni Cade, Gorilla, My Love. NY: Random House, [1972] 1992.

BECKHMAN, Barry, Jane Pittman and the Oral Tradition. Callaloo, May 1978; 1(3): 102-109.

BELL, Bernard W., The Afro-American Novel and its Tradition. Amherst: U of Massachussetts P, 1987.

BOTKIN, B.A., (ed), Lay My Burden Down: A Folk History of Slavery. NY: Delta, [1945] 1989.

BOUSON, J. Brooks, Quiet As It's Kept: Shame, Trauma, and Race in the Novels of Toni Morrison. Albany: State U of NY P, 2000.

CALLAHAN, John F., "A Moveable Form: the Loose-End Blues of The Autobiography of Miss Jane Pittman." In the African Grain: The Pursuit of Voice in Twentieth-Century Black Fiction. Urbana: U of Illinois P, 1988: 189-216. 
DAVIS, Charles T, and Henry Louis Gates, Jr., (eds). The Slave's Narrative. NY: OUP, 1985.

GAINES, Ernest, "I heard the voices... of my Louisiana people: A Conversation with Ernest Gaines. Humanities: The Magazine for the National Endowment for the Humanities. July 1998.

“Miss Jane and I." Callaloo. May 1978; 1(3): 23-38.

GATES, Henry Louis, Jr., Black Literature and Literary Theory. NY: Methuen, 1984.

The Signifying Monkey: A Theory of Afro-American Literary Criticism. NY: OUP,1988.

Figures in Black: Words, Signs, and the "Racial" Self. NY: OUP, [1987] 1989.

GAUDET, Marcia, “Miss Jane and Personal Experience Narrative: Ernest Gaines's The

Autobiography of Miss Jane Pittman." Western Folklore. January 1992; 51(1): 23-32.

HELLER, Janet Ruth, “Toni Cade Bambara's use of African American Vernacular English in 'The Lesson." Style. DeKalb: Northern Illinois U, (37:3)[Fall 2003], 279-293.

HERMAN, Judith, Trauma and Recovery. NY, NY: Basic Books, [1992] 1997.

Kirkus Reviews: A Review of The Autobiography of Miss Jane Pittman. 1971. Feb 15; 39(4): 190.

LANEY, Ruth, “A Conversation with Ernest Gaines." The Southern Review, January 1974; 10(1): 1-14.

LEPSCHY, Wolfgang, “A MELUS Interview: Ernest J. Gaines.” MELUS. March 1999; 24(1): 197-208.

LEVINE, Lawrence W., Black Culture and Black Consciousness: Afro-American Folk Thought from Slavery to Freedom. NY: OUP, 1977.

MITCHELL, Angelyn, The Freedom to Remember: Narrative, Slavery, and Gender in Contemporary Black Women's Fiction. New Brunswick, NJ: Rutgers UP, 2002.

MORRISON, Toni, Beloved. (1987). London: Picador, 1988.

MUTHER, Elizabeth, “Bambara's Feisty Girls: Resistance Narratives in Gorilla, My Love.” African American Review. Terre Haute: Indiana State U (36:3)[Fall 2002], 447-459.

ROWELL, Charles H, “"This Louisiana Thing That Drives Me': An Interview with Ernest J. Gaines." Callaloo. May 1978; 1(3): 39-51.

SMITH, Valerie, Self-discovery and Authority in Afro-American Narrative. Cambridge: Harvard UP, 1987.

STEPTO, Robert B, From Behind the Veil: A Study of Afro-American Narrative. Urbana: U of Illinois P, 1979.

WALL, Cheryl A, Worrying the Line. Chapel Hill: U. of North Carolina P, 2005.

WALKER, Alice, The Color Purple. London: Women's Press, [1983]1986.

WALKER, Margaret. Jubilee. NY: Mariner, [1966]1999.

WILLIAMS, Sherley Anne, Dessa Rose. NY: Berkley, [1986] 1987.

YETMAN, Norman, "Ex-Slave Interviews and the Historiography of Slavery." American Quarterly. June $1984 ; 36(2)$

\section{NOTES}

1. I agree with Angelyn Mitchell that "emancipatory narratives" (Mitchell, 2002, xi) is politically and aesthetically the better term, to avoid linguistic and semiotic 
entrapment in precisely what these narratives performatively undo: the word "slave" and the reification it implies as a "permanent identity," as Toni Cade Bambara has pointed out (Mitchell, 4). Mitchell credits others, such as Eleanor W. Traylor, for first using the term emancipatory (5).

2. As in most child narratives, from Huck Finn onwards, the implicit reading contract is that Jane addresses peers: her narrative is thus accessible along age and/or racial and class lines to all (black) readers. Committed black literature staging a narrator speaking in black dialect staging a child narrator, from Toni Cade Bambara's Hazel in Gorilla, $\mathrm{My}$ Love (1972), to Alice Walker's Celie in The Color Purple (1983), or Sapphire's Precious in Push (1996) explicitly play on reader identification and maximized readability.

3. She has near-fatal run-ins with hateful black overseers: on the plantation where she was a slave (11), and during her quest ("he looked just like the driver we had left on the place. The kind was used to beating on poor black people who couldn't hit back," 28). In "All Kinds of People," she and Ned meet the white woman who insults them and spews hatred out to their faces, while grudgingly giving them a drink of water and claiming to be a God-fearing Christian.

4. Jane's feelings are mixed: she resents the rough bath she gets for being "sassy" (36) to the black woman at the orphanage, but seemingly feels reassured by the verbal echo of her own ambivalence in the Freedom Bureau chief's calling her "Miss Smarty" (38) and histrionically bemoaning that he came South to be "a friend to man" only to find that the black children are "running [him] crazy" (38). This is staged as comedy.

5. Even if literacy-as-liberation is a problematic topos in African-American literature, whether in Ralph Ellison's Invisible Man, or T. Morrison's The Bluest Eye or Song of Solomon. It also seems that Gaines is signifying on Huck Finn's famous refusal of sivilization.

6. Wounded pride is generally what prompts Jane to the expression of ambivalence. Although she later bemoans the loss of colored troops after the Northern occupation ceases-"No such thing as colored troops, colored politicians, or a colored teacher anywhere near the place" (72)-when the first black soldiers she meets tease her mercilessly, she signifies on them in turn: "Not all colored is niggers, but them niggers back there." I told Ned. "Yankee uniform or no Yankee uniform, they ain't nothing but common niggers" (40).

7. Jane describes a vicious circle; because nobody would listen to her, she, in turn, could not listen.

8. The end of the chapter "Exodus" pits three words for black people against each other: "niggers" (Southern Whites); "colored" (Northern Whites); and "the people" (Miss Jane's term). When the North abandons Blacks to their fate, the vocabulary of animality resurfaces to describe the inhumanity of the black "condition" : "we was left there to root hog or die" (73).

9. "Now is the time to make real the promises of democracy. Now is the time to rise from the dark and desolate valley of segregation to the sunlit path of racial justice. Now is the time to lift our nation from the quicksands of racial injustice to the solid rock of brotherhood. Now is the time to make justice a reality for all of God's children." 10. This expression of ambivalence always ending in violence is emblematic: "acting like he was losing his best friend one second, next second he was blazing mad" (84-85). 11. I use the term as meaning the stereotype of the alienated black female slave or servant who denies her exploitation to herself, fantasizing that she is truly "part of" 
the white family. (See Mitchell, 2002, 25 for other definitions of the mammy as "obedient, long-suffering and dehumanized").

12. Although she calls Samson "Robert," this familiarity denies his inspiring fear in her, rather than it connotes affection: he is her adversary in every way.

13. Jane recognizes that she enjoys competitions among black women in the field even when the consequences are almost fatal-"The worse thing happened in the field while I was out there was that thing with Black Harriet" (137)-and even though this sort of competition mainly means higher black productivity for increased white profit. The chapter "Miss Lilly," a sustained signifying both on the delusions of the petit-bourgeois mulatto schoolteacher that she can "advance" the race, and on the backward ways of some inhabitants of the Quarters, ultimately scapegoats Miss Lilly, as the chorus "poor Miss Lilly" $(161,162)$ makes clear. The chapter ambiguously stages Miss Jane giving Miss Lilly the advice she knows Robert Samson will (164).

14. Which clash with the lyrical image of "the people" fleeing the South-in echoes of the spiritual "Go Down Moses" and its chorus "Let My People Go"-at the close of the chapter.

15. The word "travels" carries religious connotations from the chapter on Miss Jane's conversion. Religion is ambiguous: it appears to teach acquiescence-“The colored has suffered in this world, and that is true, but we know still the Lord's been good to us. Look at me: I'm more than a hundred and ten" (223)-and Miss Jane seems to forget that the churches would not help Ned. But she resolves this conflict through signifying with Just, and by following the messiah-as-liberator (Jimmy as "the One").

16. One recognizes the pitying repetition ("Jimmy, Jimmy, Jimmy") that adults used when she was bent on going to Ohio: the white lady's "child, child" (30), the hunter's "Lord, have mercy" (44-45); or later, Madame Gautier's “mon sha, mon sha, mon sha, mon sha" (99).

17. One thinks of Langston Hughes short, blues-like poem of celebration, "Still Here."

18. In the interviews, Gaines poignantly pays homage to his Aunt Augusteen, who was a "folk" storyteller, a nurturing ancestor, but whose body he had always known crippled -which may have translated, too, into an erasing of the body in the fictional character she inspired.

19. See Mitchell $(2002,10)$.

20. Jane uses the expression "just grinning" for instance, to convey the intense emotion and joy she feels when she is renamed by Corporal Brown $(8,9)$, and when she and Joe reach the ranch where he breaks horses (88).

21. The contrast with the lyrical, but tragically graphic poems on lynching in Langston Hughes's Magnolia Flowers, or with the celebrated blues song "Strange Fruit," but also with Jean Toomer's Cane, Richard Wright's or James Baldwin's short stories on lynching -all earlier works-is startling.

22. The conflation of courage with manhood, although Gaines did not mean it to be sexist, is gendered-in A Gathering of Old Men, the resolution of decades of racial terrorization, and of shame at having accepted racial shaming is resolved in the collective masculine testifying, and the young black man's performative access to pride through his "I'm a man" speech at the close of the narrative.

23. Quiet As It's Kept: Shame and Trauma, and Race in the Works of Toni Morrison (2000).

24. Mitchell specifically quotes an essay by Farah Jasmine Griffin where the terms "textual healing" describe Black women's writing as "sites of healing, pleasure, and resistance" $(2002,146)$. 
25. Africa only reappears in Miss Jane's internalized racism through stereotyping, when she calls one boy she dislikes "Monkey Boy" (and "that ugly boy there of Coon," 217).

26. Having reread Sherley Anne Williams preface to Dessa Rose, in which she explains why she chose the "interview" at the beginning of her book to restage, and counter Styron's white revisionism, I now see Gaines's intial setup as also signifying on Styron, to remind us of the fundamental issue of who tells the story, to whom.

\section{RÉSUMÉS}

This close reading of the text highlights how Miss Jane, in her double role as protagonist and narrator, shows considerable ambivalence towards friend and foe alike, with the result that the apparently transparent ideological meaning of entire episodes is blurred by what some critics have merely put down to "conservatism." I examine Miss Jane's almost constant suppression of emotion, and frequent displays of ambivalence towards other black people; her ambiguous relationship to oppressive, but familiar whites like Albert Cluveau or Robert Samson; and her conflicted relation to black heroes and heroics. Is the leading character a variation on the "mammy" who has internalized racist figures of speech, and uses contradictory images that undermine black heroics and validate white oppression? Or is Gaines's point to undo the "retrick" of heroics and of alienation alike, and, against of backdrop of constant, ordinary destruction of black lives, to cast the adult Miss Jane as a Brer Rabbit-like figure, for whom survival and resistance are both dialectically connected and opposed? Is there a contradiction between her "progress" towards resistance shown in the last section, and her metadiscursive comments in the present, and does her literally walking out of her own story give a conclusive meaning to her narrative, or does it point to the author's not having been able to resolve the ambivalence and ambiguities within the text?

\section{INDEX}

Mots-clés : conscience politique, textualité, intimité, voix, idéologie, interracialité, esthétique, ambiguïté, conservatisme, écriture féminine, Gaines Ernest J, genre social, héroïsme des hommes noirs, paternalisme, récit $\mathrm{d} \& \# 39$, esclave féministe

Keywords : political consciousness, textuality, intimacy, race relations, voice, Gaines Ernest J., stéréotype, stereotype, violence, ideology, aesthetics, signifying, trickster, ambiguity, ambivalence, black male heroism, conservatism, emotion, female writing, gender, genre, paternalism, speakerly text, womanist slave narrative, émotion

\section{AUTEUR}

MONICA MICHLIN

Monica Michlin est Maître de Conférences à l'Université Paris IV-Sorbonne. 